Original Article

\title{
VALIDATION AND APPLICATION OF RP-HPLC METHOD FOR QUANTIFICATION OF ENROFLOXACIN IN PURE AND VETERINARY DOSAGE FORMS
}

\author{
ASWATHY S. R. , MUHAS C. ${ }^{2}$, ANJALI SRUTHY S. ${ }^{2}$, DEVI SWAPNA P. V. ${ }^{3}$, GOPINATH U. ${ }^{4}$
}

1,3,4Department of Pharmaceutical Analysis, KTN College of Pharmacy, Chalavara, Puliyanamkunnu (P0), Ottappalam, Palakkad 698505, Kerala, India, ${ }^{2}$ Department of Pharmacy Practice, KTN College of Pharmacy, Chalavara, Puliyanamkunnu (PO), Ottappalam, Palakkad

698505, Kerala, India

Email: aswathysr22@gmail.com

Received: 04 Sep 2021, Revised and Accepted: 09 Dec 2021

\section{ABSTRACT}

Objective: The main objective of this study is to develop and validate a simple, new, fast, sensitive, precise and accurate RP-HPLC analytical methods have been established for the estimation of enrofloxacin in bulk and pharmaceutical dosage forms.

Methods: The present method was developed and validated on a Waters HPLC system using Phenomenex make Shimadzu $\mathrm{C}_{18}$ column $(250 \mathrm{~mm} \times$ $4.6 \mathrm{~mm}$ i.d., $5 \mu \mathrm{m}$ particle size) column was used for the separation. Best results were obtained with the mobile phase composition consisting of Acetonitrile-water $(80: 20, \mathrm{v} / \mathrm{v})$. The system was regulated at $1.0 \mathrm{ml} / \mathrm{min}$ flow rate at $270 \mathrm{~nm}$ UV detection.

Results: Enrofloxacin was eluted at 3.405 min retention time. The analytical parameters such as accuracy, precision, linearity, LOD, LOQ, ruggedness, and robustness were used for validating the developed method according to ICH guidelines. Linearity was exhibited over the concentration range of $0.1-0.6 \mu \mathrm{g} / \mathrm{ml}$ and the Limit of Detection and Quantitation values for Enrofloxacin was $0.001 \mu \mathrm{g} / \mathrm{ml}$ and $0.03 \mu \mathrm{g} / \mathrm{ml}$, respectively. The result of the analysis shows that the amount of drugs present in the formulation has a very good correlation with the label claim of the formulation and \%RSD will be less than 2 for all the validation parameters. Recoveries studies revealed that results within the specified limits.

Conclusion: The developed methods were validated for various parameters as per ICH guidelines. Hence the proposed method was found to be satisfactory and could be used for the routine analysis of enrofloxacin in their marketed formulation.

Keywords: Enrofloxacin, Method development, Method validation, RP-HPLC

(C) 2022 The Authors. Published by Innovare Academic Sciences Pvt Ltd. This is an open access article under the CC BY license (https://creativecommons.org/licenses/by/4.0/) DOI: https://dx.doi.org/10.22159/ijpps.2022v14i2.43053. Journal homepage: https://innovareacademics.in/journals/index.php/ijpps.

\section{INTRODUCTION}

Enrofloxacin is a synthetic chemotherapeutic agent from the class of the fluoroquinolone carboxylic acid derivative which was developed exclusively for use in animals [1]. Chemically it is a 1-cyclopropyl-7-(4ethyl-1-piperazinyl)-6-fluoro-1, 4-dihydro-4-oxo-3-quinoline carboxylic acid. It inhibits the bacterial DNA gyrase (a type-II topoisomerase), thereby preventing DNA supercoiling and DNA synthesis [2, 3]. It exhibits a wide spectrum of antimicrobial activity against gram-negative bacteria and intracellular organisms such as Rickettsia, Chlamydia, and Mycoplasma, and a tighter spectrum of activity against gram-positive organism's drug with a wide spectrum of activity against bacteria [4].

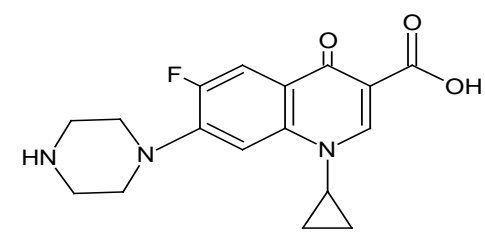

Fig. 1: Chemical structure of enrofloxacin

International trade in aquaculture has been growing continuously in recent years, and is expected to persist in the future. The variety of farmed aquatic species is now diversifying and fish farming is intensifying. At the same time, increased incidence of disease, also due to intensive aquaculture, requires more intense use of veterinary drugs and chemicals. During the last few years enrofloxacin has received growing attention because of its potential efficiency for the treatment of diseases in fish $[5,6]$.

The methods available for Enrofloxacin estimation are thin-layer chromatography (TLC)-fluorescence, capillary electrophoresis- fluorescence, Spectrophotometry $[7,8]$, high-performance liquid chromatography (HPLC)-UV or fluorescence [9-17], HPLC-Mass spectrometry (MS) or gas chromatography (GC)-MS [18]. The majority of these methods have been developed to analyze biological samples such as serum or urine. The extensive literature surveys revealed that few methods have been reported for the estimation of Enrofloxacin in pure and dosage forms.

There is a wide scope for the development of new analytical methods for the estimation of the Enrofloxacin. This paper presents simple, sensitive, accurate and reproducible RP-HPLC methods that were developed for the estimation of Enrofloxacin in bulk and veterinary dosage forms

\section{MATERIALS AND METHODS}

Chemicals and reagents

The standard drug of Enrofloxacin was collected as gift samples from Sura labs, Hyderabad. The commercial tablet dosage form was procured from a local pharmacy. Acetonitrile (HPLC grade), Methanol (HPLC grade), water (HPLC grade), and orthophosphoric acid used for the preparation of the mobile phase were a product of Merck.

Instruments used

The chromatographic system used to perform development and validation of this assay method was comprised of a LC-10ATvp binary pump, an SPD-20Avp UV-Visible detector and a Hamilton manual injector with $20 \mu \mathrm{l}$ loop (Shimadzu, Kyoto, Japan) connected to a multi-instrument data acquisition and data processing system (LC Solution, Shimadzu).

Experimental

Chromatographic conditions

Column Phenomenex $\mathrm{C}_{18}$ column ( $250 \mathrm{~mm}$ x $4.6 \mathrm{~mm}$ i. d,5 $\mu \mathrm{m}$ ) was used for separation and the mobile phase, acetonitrile and water 
(80:20), was pumped at a flow rate of $1 \mathrm{ml} / \mathrm{min}$. It was filtered through $0.20 / 0.45 \mu \mathrm{m}$ filter and degassed before use. The elution was monitored at $270 \mathrm{~nm}$ and the injection volume was $20 \mu \mathrm{L}$. The oven temperature was $40^{\circ} \mathrm{C}$.

\section{Preparation of mobile phase}

A mixture of acetonitrile and water at a ratio of 80:20 was prepared with vigorous shaking. The solution was sonicated and degas before use.

\section{Preparation of standard solutions}

$10 \mathrm{mg}$ of Enrofloxacin was weighed accurately and transferred to 10 $\mathrm{ml}$ standard flask, add $1 \mathrm{ml}$ methanol for dissolving, then add mobile phase (acetonitrile and water-80:20) and the volume made up to 10 $\mathrm{ml}$ to get a concentration of $1000 \mu \mathrm{g} / \mathrm{ml}$ (Stock solution A)

From Stock solution-A, different volume of standard solutions was taken and prepare $0.1,0.2,0.3,0.4,0.5,0.6 \mu \mathrm{g} / \mathrm{ml}$ concentration of enrofloxacin solutions.

\section{Preparation of formulation solutions}

Twenty tablets were weighed and finely powdered. From the powdered tablet, a quantity of powder equivalent to $10 \mathrm{mg}$ of enrofloxacin was weighed and extracted with mobile phase having acetonitrile and water (80:20) and finally made up with mobile phase to get a concentration of $1000 \mu \mathrm{g} / \mathrm{ml}$. From this, prepare $10 \mu \mathrm{g} / \mathrm{ml}$ of working solution. $20 \mu \mathrm{l}$ of each concentration of the drug were injected into the HPLC system and their chromatograms were recorded. Peak areas were recorded for all the peaks and a standard calibration curve of area under curve against concentration was plotted.

\section{Method validation}

The optimized chromatographic method was completely validated according to the procedures described in ICH guidelines Q2 (R1) for the validation of analytical methods [19-21].

\section{Linearity and range}

The linearity of a method is its ability to obtain test results that are directly proportional to the sample concentration over a given range of $0.1,0.2,0.3,0.4,0.5,0.6 \mu \mathrm{g} / \mathrm{ml}$ should be investigated. The relationship between sample concentration and detector response (peak area or height) was used to make this determination. Calibration curves for each method was plotted and the obtained data were subjected to regression analysis.

\section{Precision}

The reproducibility of the proposed method was determined by performing the assay for the same day (intra-day assay precision) and on three different days (inter-day assay precision). Precision studies was performed by preparing six determinations in the concentration of $0.5 \mu \mathrm{g} / \mathrm{ml}$. The results of repeatability, intra-day and inter-day precision were expressed in \% RSD.

\section{Accuracy}

In order to ensure the suitability and reliability of the proposed method, recovery studies were carried out. The accuracy study was carried out by the analysis of standard additions at three levels that is, multi-level recovery studies. To a fixed equivalent quantity of formulation powder as well as a synthetic mixture, a known quantity of standard enrofloxacin added at 50\%, $100 \%$ and $150 \%$ level and the contents was re-analyzed. The \% recovery and \%RSD were calculated.

\section{Limit of detection and limit of quantification (LOD and LOQ)}

The LOD and LOQ were separately determined based on the standard calibration curve. The residual standard deviation of the y-intercept of regression lines may be used to calculate LOD and LOQ. LOD $=3.3^{*} \mathrm{D} / \mathrm{S}$ and $\mathrm{LOQ}=10^{*} \mathrm{D} / \mathrm{S}$, where $\mathrm{D}$ is the standard deviation of the intercept of the regression line and $S$ is the slope of the calibration curve.

\section{Ruggedness}

The ruggedness of an analytical method is the degree of reproducibility of test results obtained by the analysis of the same samples under a variety of conditions, such as different laboratories, analysts, instruments. Ruggedness of the proposed method was determined by analysis of aliquots from homogenous slot by two analyst using the same operational and environmental conditions.

\section{Robustness}

The robustness of an analytical procedure is the measure of its capacity to remain unaffected by small, but deliberate, variations in method parameters and provides an indication of its reliability during normal usage. The proposed method parameters were the change of volumetric flasks $(10 \mathrm{ml}, 50 \mathrm{ml}$ and $100 \mathrm{ml})$ were performed. The robustness of was determined by different wavelengths and mobile phase flow rate. The result is expressed in Percentage RSD.

\section{System suitability}

A system suitability test of the chromatographic system was performed to ensure the validity of the analytical procedure. Five replicate injections of standard preparation were injected and tailing factor, theoretical plate and \% RSD of peak area were determined

\section{RESULTS}

\section{Method development}

In this proposed method, RP-HPLC method based on UV detection was developed and validated for the estimation of Enrofloxacin in pure and dosage forms. Phenomenex make Shimadzu $\mathrm{C}_{18}$ column (250 $\mathrm{mm} \times 4.6 \mathrm{~mm}$ i.d., $5 \mu \mathrm{m}$ particle size) column and mobile phase composition consisting of a mixture of Acetonitrile: Water $(80: 20 \mathrm{v} / \mathrm{v})$ found to be giving satisfactory results. For the selection of organic constituent of mobile phase, acetonitrile was chosen to reduce the longer retention time and to attain good peak shape. [fig. 2] represent the wavelength selection [fig. 3] represent the chromatograms of standard.

\section{Determination of wavelength of maximum absorption}

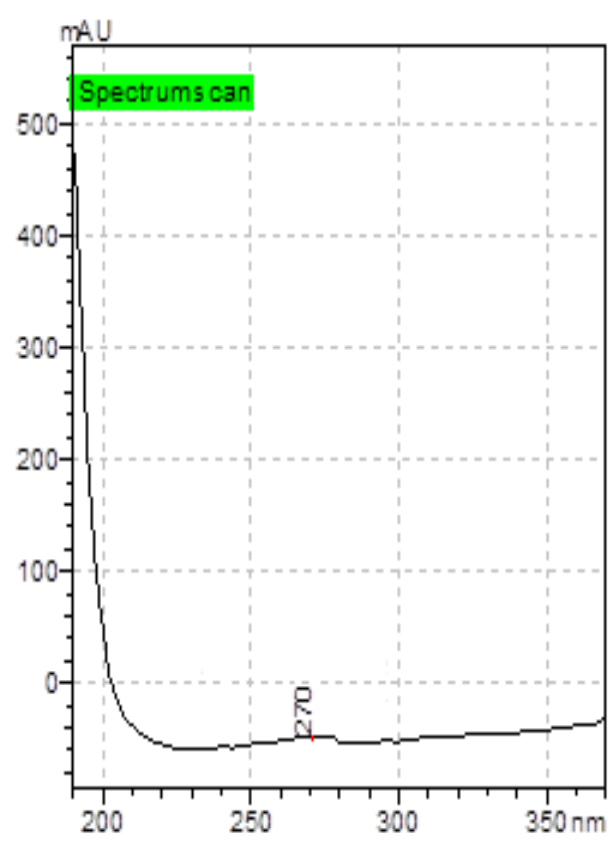

Fig. 2: HPLC scan spectrum for enrofloxacin chromatogram of standard 


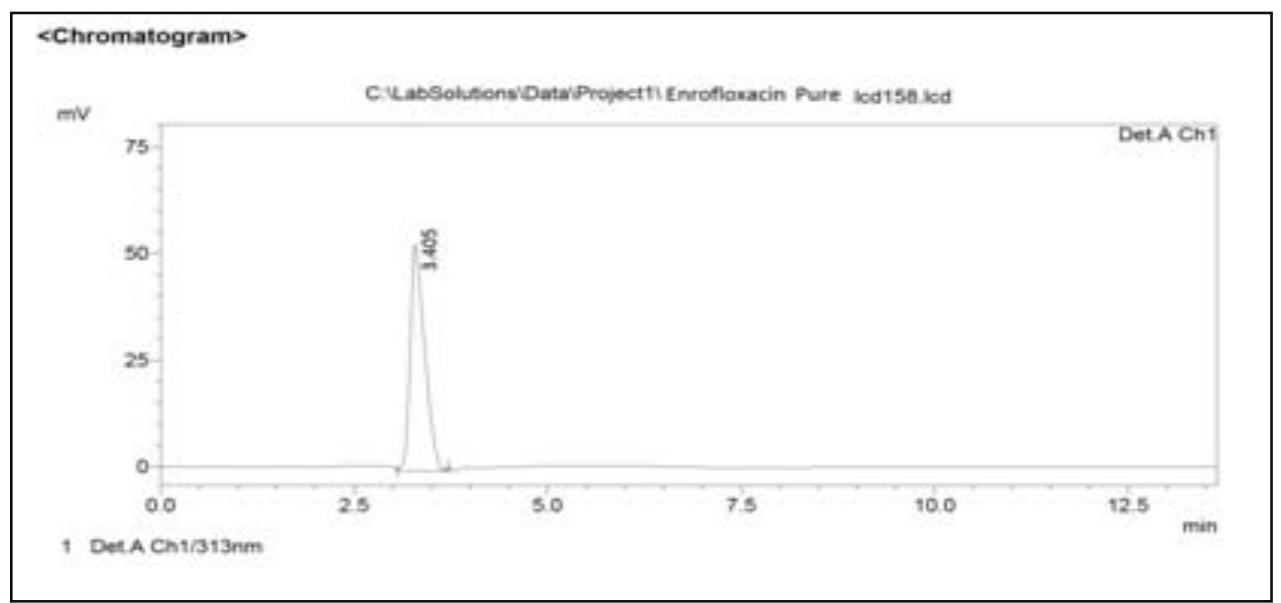

Fig. 3: Chromatogram for enrofloxacin [Std]

\section{Method validation parameters}

\section{System suitability}

All the efficiency parameters like theoretical plates were observed to be more than 7000 for Enrofloxacin. The peak tailing was not more than 2.0. The \%RSD for the five replicate injections was not more than 2.0 and ensured that the entire testing system and chemicals used could generate an accurate and precise result by showing all the efficiency parameters within the specified limits. Reported the results in tables 1 .

\section{Linearity}

For linearity, seven points calibration curve [table 2] was obtained in a concentration range from $0.1-0.6 \mu \mathrm{g} / \mathrm{ml}$ for Enrofloxacin. The response of the drug was found to be linear in the investigation concentration range and the linear regression equation for Enrofloxacin was $y=866919 x+6888.7$ with a correlation coefficient 0.9991 [fig. 4]. Where $\mathrm{x}$ is the concentration in $\mu \mathrm{g} / \mathrm{ml}$ and $\mathrm{y}$ is the peak area in the absorbance unit.

Table 1: System suitability parameters of enrofloxacin

\begin{tabular}{ll}
\hline Parameter & Enrofloxacin \\
\hline Theoretical plate & 7854 \\
Tailing factor & 0.9 \\
Retention time & 3.405 \\
Peak symmetry & 1.26 \\
Area of peak & 434592 \\
\hline
\end{tabular}

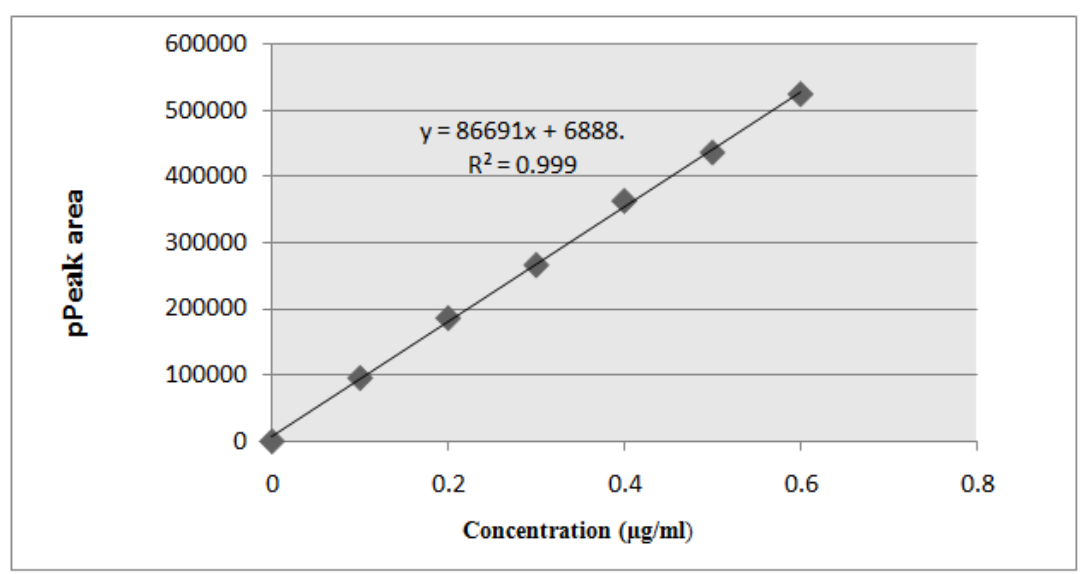

Fig. 4: Calibration curve of enrofloxacin

Table 2: Linearity data for enrofloxacin

\begin{tabular}{ll}
\hline Parameters & Data's \\
\hline$\lambda \max$ & $270 \mathrm{~nm}$ \\
Linearity $(\mu \mathrm{g} / \mathrm{ml})$ & $0.1-0.6$ \\
Correlation coefficient $\left(\mathrm{r}^{2}\right)$ & 0.9991 \\
Slope $(\mathrm{m})$ & 866919 \\
Intercept $(\mathrm{c})$ & 6888.7 \\
\hline
\end{tabular}

$\lambda \max =$ Maximum absorbance, $\mu \mathrm{g} / \mathrm{ml}=$ microgram per millilitre

\section{LOD and LOQ}

The limit of detection and limit of quantification were evaluated by serial dilutions of Enrofloxacin stock solution. The LOD value for enrofloxacin was $0.001 \mu \mathrm{g} / \mathrm{ml}$ and $\mathrm{LOQ}$ was found to be $0.03 \mu \mathrm{g} / \mathrm{ml}$. LOD and LOQ study values were shown in table [table 3]

\section{Accuracy}

The HPLC area responses for accuracy determination are depicted in [table 4]. The result shown that the best recoveries (98-102\%) of the spiked drug were obtained at each added concentration, indicating that the method was accurate.

\section{Precision}

The result of repeatability of std and inter-day and intra-day precision study are shown in [table 5]. The developed method was found to be precise as the \% RSD values for the repeatability and inter and intra-day precision studies were $<0.096 \%$ and $<0.268 \%$, respectively, which confirms that method was precise. 
Table 3: LOD and LOQ for enrofloxacin

\begin{tabular}{llll}
\hline Method & Detection wavelength $(\mathbf{n m})$ & LOD $(\boldsymbol{\mu g} / \mathbf{m l})$ & LOQ $(\boldsymbol{\mu g} / \mathbf{m l})$ \\
\hline Proposed Method & $270 \mathrm{~nm}$ & 0.001 & 0.03 \\
\hline
\end{tabular}

LOD=Limit of Detection, $\mathrm{LOQ}=$ Limit of Quantification, $\mu \mathrm{g} / \mathrm{ml}=$ microgram per millilitre

Table 4: Accuracy data for enrofloxacin

\begin{tabular}{|c|c|c|c|c|c|}
\hline $\begin{array}{l}\text { Level of addition (\%pure } \\
\text { drug) } n=3\end{array}$ & $\begin{array}{l}\text { Con. of drug in } \\
\text { formulations }(\mu \mathrm{g} / \mathrm{ml})\end{array}$ & $\begin{array}{l}\text { Conc. drug } \\
(\mu \mathrm{g} / \mathrm{ml}) \text { of pure }\end{array}$ & $\begin{array}{l}\text { Total conc. of the } \\
\text { drug found }(\mu \mathrm{g} / \mathrm{ml})\end{array}$ & $\begin{array}{l}\text { \% Analytical } \\
\text { recovery }\end{array}$ & Data \\
\hline $50 \%$ & 0.5 & 0.25 & 0.749 & 99.86 & Mean $=99.816$ \\
\hline $50 \%$ & 0.5 & 0.25 & 0.749 & 99.86 & $\mathrm{SD}=0.075$ \\
\hline $50 \%$ & 0.5 & 0.25 & 0.748 & 99.73 & $\% \mathrm{RSD}=0.075$ \\
\hline $100 \%$ & 0.5 & 0.5 & 0.998 & 99.8 & Mean $=100.233$ \\
\hline $100 \%$ & 0.5 & 0.5 & 1.006 & 100.6 & $\mathrm{SD}=0.4041$ \\
\hline $100 \%$ & 0.5 & 0.5 & 1.003 & 100.3 & $\% \mathrm{RSD}=0.403$ \\
\hline $150 \%$ & 0.5 & 0.75 & 1.248 & 99.84 & Mean $=99.653$ \\
\hline $150 \%$ & 0.5 & 0.75 & 1.246 & 99.68 & $\mathrm{SD}=0.2013$ \\
\hline $150 \%$ & 0.5 & 0.75 & 1.243 & 99.44 & $\%$ RSD $=0.202$ \\
\hline
\end{tabular}

$\mathrm{SD}=$ Standard deviation, $\mathrm{RSD}=$ Relative standard deviation, $\mathrm{n}=$ number, $\mu \mathrm{g} / \mathrm{ml}=$ microgram per millilitre

Table 5: Precision for enrofloxacin

\begin{tabular}{|c|c|c|c|c|c|c|}
\hline \multicolumn{4}{|c|}{ Intraday [n=6] } & \multicolumn{3}{|c|}{ Interday [n=6] } \\
\hline $\begin{array}{l}\text { Conc. } \\
(\mu \mathrm{g} / \mathrm{ml})\end{array}$ & $\begin{array}{l}\text { Peak area } \\
\text { (1) }\end{array}$ & $\begin{array}{l}\text { Peak area } \\
\text { (2) }\end{array}$ & $\begin{array}{l}\text { Peak area } \\
\text { (3) }\end{array}$ & $\begin{array}{l}\text { Peak area } \\
(D-1)\end{array}$ & $\begin{array}{l}\text { Peak area } \\
\text { (D-2) }\end{array}$ & $\begin{array}{l}\text { Peak area } \\
(D-3)\end{array}$ \\
\hline 0.5 & 435524 & 437134 & 438548 & 436159 & 438546 & 441562 \\
\hline 0.5 & 434258 & 437232 & 437562 & 436298 & 439258 & 439265 \\
\hline 0.5 & 434582 & 437689 & 438556 & 436623 & 439236 & 439874 \\
\hline 0.5 & 435692 & 436313 & 437584 & 436325 & 439658 & 440321 \\
\hline 0.5 & 435268 & 437819 & 437685 & 437819 & 439684 & 440687 \\
\hline 0.5 & 435879 & 437132 & 439665 & 437132 & 438987 & 441698 \\
\hline Mean & 435200.5 & 437068.3 & 438266.7 & 436726 & 439228.2 & 440567.8 \\
\hline SD & 642.289 & 702.160 & 826.936 & 638.054 & 428.253 & 950.741 \\
\hline$\%$ RSD & 0.147 & 0.160 & 0.188 & 0.146 & 0.097 & 0.215 \\
\hline
\end{tabular}

$\mathrm{SD}=$ Standard deviation, $\mathrm{RSD}=$ Relative standard deviation, $\mathrm{n}=$ number, $\mu \mathrm{g} / \mathrm{ml}=$ microgram per millilitre

\section{Ruggedness}

The robustness method was studied and the results are given in [table 6]. The ruggedness of the methods was conducted by two different analyst and \%RSD was calculated. Variation in percentage content was found to be within the limit so the method is rugged.

\section{Robustness}

The result of the robustness study of the developed assay method was established in [table 7 and 8]. The result shown that during all variance conditions, assay value of the test preparation solution was not affected and it was in accordance with that of actual. Hence the analytical method would be concluded as robust.

Table 6: Ruggedness of enrofloxacin

\begin{tabular}{llll}
\hline S. No. & Conc. $(\boldsymbol{\mu g} / \mathbf{m l})(\mathbf{n}=6)$ & Analyst-1 & Analyst-2 \\
\hline 1 & & 434524 & 434351 \\
2 & 0.5 & 434258 & 433547 \\
3 & & 433582 & 433554 \\
4 & & 434692 & 434968 \\
5 & & 434268 & 434321 \\
6 & & 434879 & 434877 \\
Mean & & 434367.2 & 434269.7 \\
S.D & & 453.943 & 466.473 \\
\%RSD & 0.104 & 0.114 \\
\hline
\end{tabular}

$\mathrm{SD}=$ Standard deviation, $\mathrm{RSD}=$ Relative standard deviation, $\mathrm{n}=$ number, $\mu \mathrm{g} / \mathrm{ml}=$ microgram per millilitre

Table 7: Robustness studies of enrofloxacin (Change flow rate)

\begin{tabular}{llll}
\hline S. No. & Flow rate $\mathbf{~ m l} / \mathbf{m i n}(\mathbf{n}=\mathbf{3})$ & Peak area & Statistical data \\
\hline 1 & $1.0 \mathrm{ml} / \mathrm{min}$. & 434524 & Mean=434903 \\
& & 435598 & $\mathrm{SD}=602.711$ \\
& & 434587 & \% $\mathrm{RSD}=0.138$ \\
2 & $0.5 \mathrm{ml} / \mathrm{min}$. & 432587 & Mean=432262.67 \\
& & 432987 & $\mathrm{SD}=929.933$ \\
& & 431214 & \% RSD 0.215 \\
\hline
\end{tabular}

$\mathrm{SD}=$ Standard deviation, $\mathrm{RSD}=$ Relative standard deviation, $\mathrm{n}=$ number, $\mu \mathrm{g} / \mathrm{ml}=$ microgram per millilitre 
Table 8: Robustness of enrofloxacin at change in wavelength

\begin{tabular}{|c|c|c|c|c|}
\hline S. No. & Wavelength $[\mathrm{n}=3]$ & Peak area & Statistical data & Retention time \\
\hline \multirow[t]{3}{*}{1} & $270 \mathrm{~nm}$ & 434692 & Mean=100.266 & 3.402 \\
\hline & & 434268 & $\mathrm{SD}=0.2730$ & 3.402 \\
\hline & & 434879 & $\% \mathrm{RSD}=0.272$ & 3.401 \\
\hline \multirow[t]{3}{*}{2} & $269 \mathrm{~nm}$ & 528471 & Mean=100.266 & 5.405 \\
\hline & & 528478 & $\mathrm{SD}=0.2730$ & 5.405 \\
\hline & & 527458 & $\% \mathrm{RSD}=0.272$ & 5.408 \\
\hline
\end{tabular}

$\mathrm{SD}=$ Standard deviation, $\mathrm{RSD}=$ Relative standard deviation, $\mathrm{n}=$ number, $\mu \mathrm{g} / \mathrm{ml}=$ microgram per millilitre

\section{Estimation}

The content of enrofloxacin in the marketed brands was determined. The percentages of individual drugs found in formulations, amount and relative standard deviation in formulations were calculated. The result of analysis [table 9] shows that the amount of drugs present in the formulation has a very good correlation with the label claim of the formulation. The chromatogram of enrofloxacin shown in fig. 5.

Table 9: Estimation of enrofloxacin

\begin{tabular}{|c|c|c|c|c|}
\hline Tablet brand name & Labelled amount (g) & Estimated amount (mean \pm SD) & \% Label claim & \%RSD \\
\hline Brand-A & 0.05 & $0.0503 \pm 0.00011$ & $100.6 \%$ & 0.198 \\
\hline Brand-B & 0.05 & $0.0498 \pm 0.00048$ & $99.6 \%$ & 0.240 \\
\hline
\end{tabular}

Amount of Enrofloxacin is expressed as mean \pm SD $(n=3)$

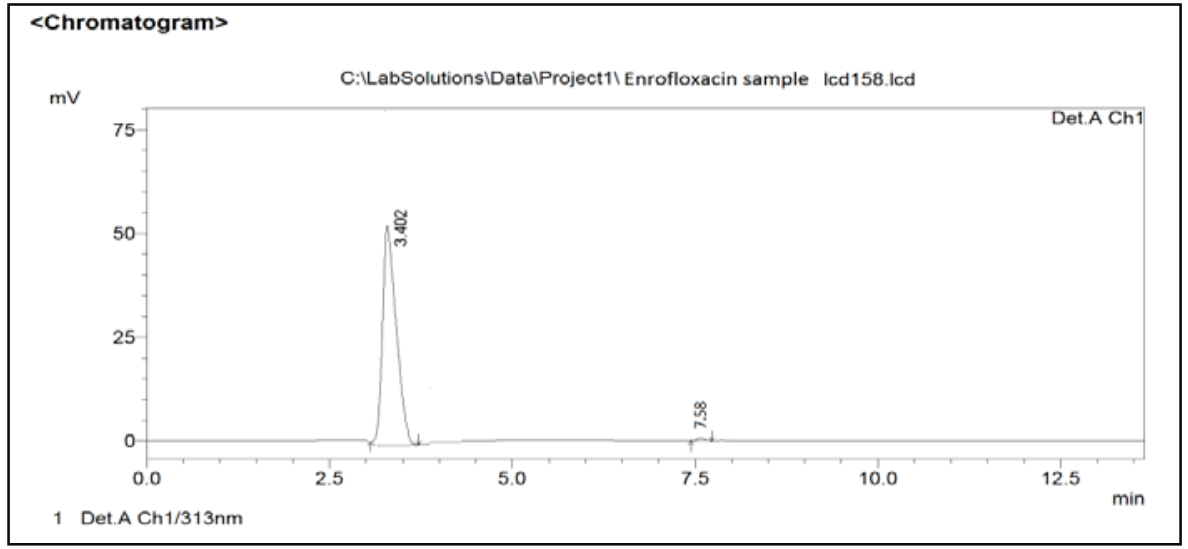

Fig. 5: Chromatogram for enrofloxacin [Sample]

\section{DISCUSSION}

The methods available for Enrofloxacin estimation are thin-layer chromatography (TLC)-fluorescence, capillary electrophoresisfluorescence, Spectrophotometry [7, 8], high-performance liquid chromatography (HPLC)-UV or fluorescence [9-17], HPLC-Mass spectrometry (MS) or gas chromatography (GC)-MS [18]. The majority of these methods have been developed to analyze biological samples such as serum or urine.

We present a simple, new, fast, sensitive, precise and accurate RPHPLC analytical method for quantification of Enrofloxacin present in the marketed formulation using reverse-phase Phenomenex $\mathrm{C}_{18}$ column ( $250 \mathrm{~mm} \times 4.6 \mathrm{~mm}$ i. $\mathrm{d}, 5 \mu \mathrm{m}$ ) with a mobile phase composed of acetonitrile: water in the ratio of $80: 20 \mathrm{v} / \mathrm{v}$. The method is highly specific as there was no interference observed between chromatograms of blank, standard and sample. The analysis was carried out in an isocratic mode at the flow rate of $1.0 \mathrm{ml} / \mathrm{min}$, at 25 ${ }^{\circ} \mathrm{C}$ and detection was carried out at $270 \mathrm{~nm}$. Good linearity with the coefficient of correlation 0.9991 indicated that the proposed method was linear within the range of $0.1-0.6 \mu \mathrm{g} / \mathrm{ml}$ compared to prevaling method having linearity with a coefficient of correlation 0.9961 and flow rate of $3.0 \mathrm{ml} / \mathrm{min}$ [12]. Accuracy results displayed good reproducibility with \% RSD below $2 \%$. The recovery of analyte in the prevailing methods was only $93 \%$ when compared with our present work $[8,9]$. The method was found to be accurate as the values observed for Brand A (100.6\%) and Brand B (99.23\%), respectively which was well within the range of $98-102 \%$ as shown in table 9. The results for precision were expressed in \% RSD as tabulated in table 5 . Whereas, The \%RSD for intra and inter-day precision of enrofloxacin was observed below $2 \%$. The low values of $\%$ RSD indicates that the method is precise and also the LOD and LOQ values showed the method was sensitive for the quantification of enrofloxacin in pure and veterinary formulation.

\section{CONCLUSION}

The established present method revealed that it is simple, selective, specific, and can generate accurate and precise results. Moreover, the shorter duration of analysis time and lesser mobile phase consumption confirmed that the method is rapid and economical. The result of analysis shows that the amount of drugs present in the formulation has a very good correlation with the label claim of the formulation and \%RSD will be less than 2 for all the validation parameters. Recoveries studies revealed that results within the specified limits. Hence the proposed method was found to be satisfactory and could be used for the routine analysis of enrofloxacin in their marketed formulation.

\section{ACKNOWLEDGEMENT}

The authors are thankful to Mr. P. P. Prem Krishnan, Managing Trustee, KTN College of Pharmacy, Chalavara, Ottappalam, Palakkad, Kerala for providing the necessary infrastructure and facility to carry out the research work. 


\section{FUNDING}

Nil

\section{AUTHORS CONTRIBUTIONS}

We declare that it's an original research work which was carried out by Mrs. Aswathy SR and Devi Swapna PV, Mrs Anjali Sruthy S and Mr. Gopinath U were carried out the validation of proposed method. Dr. Muhas C proofread the manuscript, suggested the necessary corrections, and helped in writing the manuscript.

\section{CONFLICT OF INTERESTS}

Declared none

\section{REFERENCES}

1. Hooper DC, Wolfson JS. Quinolone antimicrobial agents. 2nd ed. London: Penguin; 1993. p. 59-75.

2. Brown SA. Fluoroquinolones in animal health. J Vet Pharmacol Ther. 1996;19(1):1-14. doi $10.1111 / \mathrm{j} .1365-$ 2885.1996.tb00001.x, PMID 8992019.

3. Elmas M, Tras B, Kaya S, Bas AL, Yazar E, Yarsan E. Pharmacokinetics of enrofloxacin after intravenous and intramuscular administration in Angora goats. Can J Vet Res. 2001;65(1):64-7. PMID 11227198.

4. Riviere J, Craigmill AL, Sundlo SF. Handbook of comparative pharmacokinetics and residues of veterinary antimicrobials. Boca Raton, FL: CRC Press Press; 1991. p. 339-407.

5. Prescott JF, Baggott JD. editors. Antimicrobial therapy in veterinary medicine. Vol. 2. Ames, IA: Iowa State University Press; 1993. p. 119-26.

6. Plumb DC. Veterinary drug handbook. Pharma Vet Publishing; 1991. p. 520-9.

7. Imre S, Dogaru MT, Vari CE, Muntean T, Kelemen L. Validation of an HPLC method for the determination of ciprofloxacin in human plasma. J Pharm Biomed Anal. 2003;33(1):125-30. doi: 10.1016/s0731-7085(03)00151-1. PMID 12946539.

8. Garcia MA, Solans C, Aramayona JJ, Rueda S, Bregante MA, de Jong A. Simultaneous determination of enrofloxacin and its primary metabolite, ciprofloxacin, in plasma by HPLC with fluorescence detection. Biomed Chromatogr. 1999;13(5):350-3. doi: $\quad 10.1002 /($ SICI)1099-0801(199908)13:5<350:AIDBMC889>3.0.CO;2-C, PMID 10425026.

9. Mostafa S, El-sadek M, alla EA. Spectrophotometric determination of enrofloxacin and pefloxacin through ion-pair complex formation. J Pharm Biomed Anal. 2002;28(1):173-80. doi: 10.1016/s0731-7085(01)00591-x, PMID 11861121.

10. Gigosos PG, Revesado PR, Cadahía O, Fente CA, Vazquez BI, Franco CM, Cepeda A. Determination of quinolones in animal tissues and eggs by high-performance liquid chromatography with photodiode-array detection. J Chromatogr A. 2000;871(12):31-6. doi: 10.1016/S0021-9673(99)01048-1.

11. Patel KM, Suhagia BN, Singhvi I. Analytical method development and validation for enrofloxacin in bulk and formulation by RP-HPLC method. AJPTR 2018;8(2):176-85. doi: 10.46624/ajptr.2018.v8.i2.013.

12. da Silva Anacleto S, Teixeira LS, Borges MMC, Moraes CT, de Souza Borges W, Pereira AC, Borges KB. A simple and rapid HPLC method for the multidetermination of enrofloxacin, ciprofloxacin, and oxytetracyclin in raw materials and veterinary pharmaceutical formulations. Curr Pharm Anal. 2018;14(4):397-404. $10.2174 / 1573412913666170613091914$.

13. Brahma Reddy, DR Reddy, DPK Konda B. Method development and validation for estimation of enrofloxacin by RP-LC in marketed formulations. Int J Pharm Sci Lett. 2015;5:624-6.

14. Tauber VP, Chiurciu V. Development and validation of an HPLC method for the determination of oxytetracycline and enrofloxacin in veterinary formulations. Medicam Vet Vet Drug. 2015;9:65-9.

15. Prasad KB, Murthy TGK. Analytical method development and validation for the estimation of enrofloxacin in small-volume parenteral formulation by HPLC method. J Pharm Res. 2010;3:1128-30.

16. Souza MJ, Bittencourt CF, Morsch LM. LC determination of enrofloxacin. J Pharm Biomed Anal. 2002;28(6):1195-9. doi: 10.1016/s0731-7085(01)00673-2, PMID 12049983.

17. Sumithra S, PS, VR. Quality by design-based optimization and validation of new reverse phase-high-performance liquid chromatography method for simultaneous estimation of levofloxacin hemihydrate and ambroxol hydrochloride in bulk and its pharmaceutical dosage form. Asian J Pharm Clin Res. 2016;9(9):190-6. doi: 10.22159/ajpcr.2016.v9s3.14040.

18. Krishna KJ, Prasada RK. Novel validated headspace gas chromatography method for the simultaneous quantification of three volatile organic impurities in enrofloxacin pure and pharmaceutical dosage forms. Asian J Pharm Clin Res. 2020;13(11):171-7.

19. Richez P, Monlouis JD, Dellac D, Daube G. Validation of a therapeutic regimen for enrofloxacin in cats on the basis of pharmacokinetic data. J Vet Pharmacol Ther. 1997;20(10):152-3.

20. International conference on harmonization. ICH harmonized tripartite guideline. Validation of Analytical Procedures: Text and Methodology. Vol. Q2; 2005. p. R1.

21. US Food and Drug Administration. Guidance for industry. Silver Spring, MD: Analytical Procedures and Methods Validation for Drugs and Biologics, US Food and Drug Administration; 2015. 